\title{
A large submucous uterine leiomyoma and pregnancy: clinical case
}

\section{Tatyana Slobodchikova, Irina Evgeneva}

Obstetrics and Gynecology, Perinatology Department, Karaganda Medical University, Karaganda city, Republic of Kazakhstan

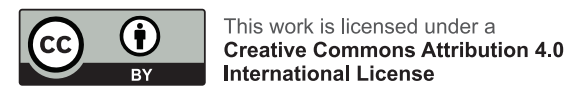

Received: 2019-10-17

Accepted: 2019-12-22

UDC: 616.1

\section{J Clin Med Kaz 2019; 4(54):45-46}

Corresponding Author: Tatyana Slobodchikova, Obstetrics and Gynecology, Perinatology Department, Karaganda Medical University, Karaganda city, Republic of Kazakhstan. Tel.: +77013965482

E-mail: super-elvie@mail.ru

\begin{abstract}
Leiomyoma (or uterine myoma) is the most widespread tumor, which occupies the 2nd place in the structure of gynecological diseases, after inflammatory diseases of the pelvic organs. Leiomyoma negatively affects the reproductive health of women and their life quality. Ultrasound examination is a reliable and affordable method for uterine myoma detecting. Timely conservative and organ-preserving treatment at the stage of pregravid preparation will favorably keep women's reproductive potential.
\end{abstract}

Keywords: pregnancy, uterine leiomyoma, subserous myomatous node

\section{ЖАТЫР ӨЛШЕМІ МЕН ЖҮКТІЛІККЕ ЖАТАТЫН СУБМУКОЗДЫ ЖАТЫР МИОМАСЫ: КЛИНИКАЛЫК ЖАҒДАЙ}

\section{Т.С. Слободчикова, И.А. Евгеньева}

Акушерлік, гинекология және перинатология кафедрасы, Қарағанды Медицина Университеті, Қарағанды қаласы, Қазақстан Республикасы

\section{ТҰЖЫРЫМДАМА}

Лейомиома (немесе жатыр миомасы) - бұл жамбас мүшелерінің қабыну ауруларынан кейін гинекологиялық аурулардың құрылымында 2-ші орынды алатын ең көп таралған ісік. Лейомиома әйелдердің репродуктивті денсаулығы мен өмір сүру сапасына теріс әсер етеді. Ультрадыбыстық зерттеу - жатырдың миомасын анықтайтын қауіпсіз және қол жетімді әдіс. Програвидті дайындау кезеңінде уақытылы және ағзаны сақтайтын емдеу әйелдердің репродуктивті әлеуетін сақтайды.

Негізгі сөздер: жүктілік, жатырдың лейомиомасы, қосалқы миоматозды түйін

\section{СУБМУКОЗНАЯ МИОМА МАТКИ БОЛЬШИХ РАЗМЕРОВ И БЕРЕМЕННОСТЬ: КЛИНИЧЕСКИЙ СЛУЧАЙ}

\section{Слободчикова Т.С., Евгеньева И.А.}

Кафедра акушерства и гинекологии, перинатологии, Медицинский Университет Караганды, город Караганда, Республика Казахстан

\section{PЕЗЮМЕ}

Лейомиома (или миома матки) - это наиболее распространенная опухоль, занимающая 2-е место в структуре гинекологических заболеваний после воспалительных заболеваний органов малого таза. Лейомиома негативно сказывается на репродуктивном здоровье и качестве жизни женщин. Ультразвуковое исследование является безопасным и доступным методом обнаружения миомы матки. Своевременное и органосохраняющее лечение на стадии прегравидарной подготовки благоприятно сохранит репродуктивный потенциал женщин.

Ключевые слова: беременность, лейомиома матки, субсерозный миоматозный узел

\section{Introduction}

Leiomyoma or uterine myoma (hysteromyoma) is a monoclonal tumor that develops from a single mutant smooth muscle cell of the vascular wall without the ability of growth control [1-4]. It can be detected in $77 \%$ of women in the population, and there is a tendency to «rejuvenation» of the disease over the past 10 years: in Russia, its prevalence in women under the age of 30 years increased from $2 \%$ to $12.5 \%$, in the USA, in women of $18-30$ years - to $43-57 \%$ [2,4]. Risk factors predisposing to the development of uterine myoma are numerous, they include: burdened genetic history, age, low parity, obesity, artificial birth control, hormonal menopausal therapy, tamoxifen intake, genitals chronic inflammatory diseases. Controversial issues of uterine myoma pathogenesis make equal the existence of different theories of this tumor development. There are several classifications of uterine fibroids, but clinicians are widely use clinical and anatomical classification, which is based on tumor growth in relation to the muscular layer of the uterus and the localization of myoma in different parts of the uterus: subserous, submucous, intraligmental, cervical. In 95\% of cases, myoma is located in the uterus body, in 5\% - in its neck (cervical fibroids) [1,2]. Clinical manifestations of uterine myoma depend on the tumor location, its size and woman age. Sometimes myoma is asymptomatic disease for a long time, but it is often accompanied by abundant and prolonged menstruation, having the nature of bleeding. Myoma leads to infertility and/ 
or miscarriage in $30 \%$ of cases in women of reproductive age $[1,3]$. Ultrasound research is the main method of screening and primary diagnosis of hysteromyoma. Ultrasound examination allows determining the number, localization, diameter, structure, echogenicity of nodes. The variants for uterine myoma treatment are diverse-surgical, radiological and medical. The choice of treatment method depends on the woman's age, tumor size, symptoms severity, the number and location of nodes, the risk of malignancy, reproductive goals, on the desire to preserve the uterus [1-4]. But there is always a risk of recurrence after organsaving operations, which reaches $15-45 \%$ [2].

\section{Case presentation}

In May, 2017, the patient P., 28 years old, was delivered by ambulance to the Regional obstetric and gynecological center of Karaganda from the Central regional hospital. The patient had pregnancy period of 36 weeks +4 days, complaints of cramping pains in the lower abdomen, pain in the lumbar region and bloody discharge from the genital tract.

The disease history: this pregnancy was 5 th, 2 pregnancies of the patient ended by well-time labor, and 2 pregnancies by artificial abortions without complications. The history of gynecological diseases included hysteromyoma, which was diagnosed in 2015, and then the patient was not observed by gynecologist. This pregnancy occurred spontaneously, proceeded against the threat of pregnancy termination and was complicated by gestational pyelonephritis at the $21 \mathrm{st}$ week of pregnancy. Ultrasound research at 11 weeks determined subserous uterine leiomyoma, but the patient was registered for pregnancy only at 20 weeks. Ultrasound research in the period of 21 weeks of pregnancy diagnosed low placentation and the size of the subserous myomatous node $70 \times 85 \mathrm{~mm}$. General condition was satisfactory. Blood pressure was 120/80 mm Hg, pulse 74 beats per minute, rhythmic. The patient's abdomen was enlarged due to the pregnant uterus; hypertonus of the uterus is registered. The position of the fetus was longitudinal, the head lied above the entrance to the pelvis. Fetal heartbeat was muffled, rhythmic -144 per minute. Bleeding of genital tract was in a volume of $50 \mathrm{ml}$. Clinical diagnosis was pregnancy of 36 weeks +4 days.

It was diagnosed total premature detachment of the normally located placenta, uterine leiomyoma. The patient urgently underwent cesarean section, during which a live premature fetus weighing 2530, $46 \mathrm{~cm}$ tall was extracted for the head with Apgar score of 7-8 points, then - supravaginal amputation of the uterus without appendages.

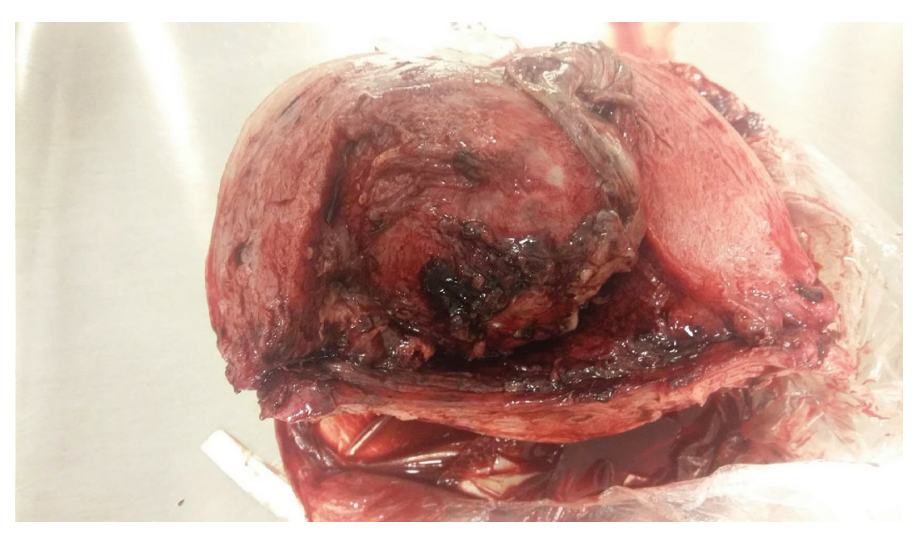

Figure 1 - Macro preparation of the uterus in the sagittal incision. Along the rear wall in the bottom on the left you may see a submucose node $10 \times 10 \mathrm{~cm}$ on the wide base.

Intraoperative blood loss was $700 \mathrm{ml}$. The resulting macropreparation was presented by uterine body, submucous node of $10 \times 10 \mathrm{~mm}$ on a wide base was determined along the back wall in the bottom on the left, there was a partially placental site on the node (Figure 1). The postoperative period (early and late) proceeded without complications, the patient with the child were discharged from hospital on the 7 th day.

\section{Discussion}

Recently, there has been an increase in patients of reproductive age with uterine myoma, planning pregnancy. At the same time, the doctor is faced with questions how to improve the outcomes of pregnancies with uterine myoma and minimize complications for both the mother and the fetus. Pregnant women with uterine myoma are in high risk group for miscarriage and they require personalized gynecological and obstetric tactics.

Fetoplacental insufficiency, fetal development delay, preeclampsia in patients with leiomyoma is observed no more often than in pregnant women without this pathology. But it must be remembered that uterine myoma increase the frequency of premature birth, can cause premature detachment of the normally located placenta, especially if the placenta is partially located in the projection of the myomatous node, which took place in presented clinical case. Pregnant women with uterine myoma require careful pregravid preparation and special attention of the doctor of female consultation.

Disclosures: There is no conflict of interest for all authors. Patient informed consent: obtained.

\section{References}

1. Kudrina Ye. A., Baburin D. V. Uterine myoma: current aspects of pathogenesis and treatment (Mioma matki: sovremennye aspekty patogeneza i lechenija) [in Russian]. Arhiv akusherstva i ginekologii im. V. F. Snegiryova. 2016; 3(1):4-10 https://doi. org/10.18821/2313-8726-2016-3-1-4-10

2. Mitichkin A. E., Dobrohotova Ju. Je., Ivannikov N. Ju., Dimitrova V. I., Sljusareva O. A., Hlynova S. A., Ljubeshkina V. A., Mustafaeva T. G. Improving reproductive outcomes after treating uterine myoma (Uluchshenie reproduktivnyh ishodov posle lechenija miomy matki) [in Russian]. Medicinskij sovet. 2019; 7:110-118 https://doi.org/10.21518/2079-701X-2019-7-110-118

3. Egamberdieva L. D., Tuhvatshina N. I., Muhametzjanova L. M. Features of the pregnancy and childbirth in patients with uterine myoma (Osobennosti techenija beremennosti i rodov u pacientok s miomoj matki) [in Russian]. Prakticheskaja medicina. 2017; 8(109):190-193

4. Barinov S.V., Shamina I.V., Tirskaya Y.I., Lazareva O.V., Dudkova G.V., Frickel E.A., Ledovskikh I.O., Shishkina M.I., Stotskaya T.A. Original article: management of pregnant women with large uterine fibroids. Fundamental and Clinical Medicine. 2018; 3(2):34-41 https://doi.org/10.23946/2500-0764-2018-3-2-34-41

How to cite this article: Tatyana Slobodchikova, Irina Evgeneva. A large submucous uterine leiomyoma and pregnancy: clinical case:. J Clin Med Kaz. 2019; 4(54):45-46 